\title{
Variation in faecal corticosterone metabolites in an Arctic seabird, the Little Auk (Alle alle) during the nesting period
}

\author{
Dorota Kidawa $\cdot$ Katarzyna Wojczulanis-Jakubas • \\ Dariusz Jakubas • Rupert Palme • Lech Stempniewicz • \\ Mateusz Barcikowski • Liliana Keslinka-Nawrot
}

Received: 6 September 2013/Revised: 18 December 2013/Accepted: 28 January 2014/Published online: 15 February 2014

(C) The Author(s) 2014. This article is published with open access at Springerlink.com

\begin{abstract}
Glucocorticoids participate in the control of whole body homoeostasis and an organism's response to stress. Corticosterone, which is the principal glucocorticoid in birds, has been shown to increase in response to different energetic demands and perturbations that individuals have to cope with. In this study, a non-invasive method to examine the corticosterone secretion by measuring faecal corticosterone metabolites (FCM) has been established for an Arctic seabird, the Little Auk (Alle alle). A group-specific immunoassay was successfully validated for adults and chicks using an adrenocorticotropic challenge test. Then, FCM levels were investigated under different energetic and physiological demands, determined by weather conditions, week of chick rearing in adults, and age in chicks. The amount of rainfall had no effect on FCM levels in adults, whereas it negatively affected FCM levels in chicks. There was no variation in FCM concentrations among weeks of chick rearing in adults. In chicks, the FCM levels increased with age. Moreover, chicks with higher FCM levels had lower body mass and fledged later than chicks with lower FCM levels. This study demonstrates that environmental stress such as poor weather conditions can trigger significant changes in corticosterone levels in seabird chicks. Furthermore, the results indicate that corticosterone may be involved in the physiological and behavioural adjustments necessary for successful fledging and post-fledging survival.
\end{abstract}

D. Kidawa $(\bowtie) \cdot$ K. Wojczulanis-Jakubas · D. Jakubas .

L. Stempniewicz · M. Barcikowski · L. Keslinka-Nawrot Department of Vertebrate Ecology and Zoology, University of Gdańsk, ul. Wita Stwosza 59, 80-308 Gdańsk, Poland

e-mail: dorotakidawa@univ.gda.pl

R. Palme

Department for Biomedical Sciences/Biochemistry, University of Veterinary Medicine, Veterinärplatz 1, 1210 Vienna, Austria
Keywords Faecal corticosterone - Non-invasive method · Stress $\cdot$ Weather $\cdot$ Chick age $\cdot$ Seabird

\section{Introduction}

During the nesting period, birds experience unpredictable environmental events, such as adverse weather conditions, that can lead to physiological stress reactions. However, predictable demands of the life cycle (breeding in adults, fledging in chicks) can also challenge an individual. Glucocorticoids, the end hormones of the hypothalamicpituitary-adrenal axis, are one of the front-line hormones that participate in the control of whole body homoeostasis and the organism's response to stress (Möstl and Palme 2002; Landys et al. 2006). Secreted glucocorticoids may change behaviour, mobilise energy reserves (Möstl and Palme 2002; Romero 2002), as well as prime other physiological systems (e.g. epinephrine action) to work better under stress (Sapolsky et al. 2000). Furthermore, severe stress can change metabolic pathways, so that individuals increasingly rely on the catabolism of proteins to fuel their activities (Axelrod and Reisine 1984; Cherel et al. 1992). The level of the principal glucocorticoid in birds, corticosterone, has been shown to increase in response to season changes, weather deterioration and periodic life processes (Heath 1997; Belthoff and Dufty 1998; Romero et al. 2000; Romero 2002; Frigerio et al. 2004; Landys et al. 2006; Quillfeldt et al. 2010). Furthermore, increased baseline corticosterone levels have been suggested as a reliable indicator of poor condition or health, thus reflecting how an individual or population copes with their environment (reviewed in Bonier et al. 2009; Angelier et al. 2010).

Commonly, baseline corticosterone level is established based on its concentration in plasma. However, constraints 
of the blood sampling procedure pose some limitations to this approach due to the amount of the blood necessary to establish the hormone concentration. An adequate blood sample is particularly difficult to obtain in small animals, such as many birds. A further limitation of blood sampling is that the sample have to be collected immediately after capture (within 2-3 min), since the circulating hormone levels are affected in response to the stress of handling, physical restraint and the blood sampling procedure itself (Wingfield 1994; Romero and Reed 2005; Touma and Palme 2005; Landys et al. 2006; Sheriff et al. 2011). Therefore, measuring faecal corticosterone metabolites (FCM) has been proposed as a non-invasive, alternative method to examine hormone levels. Moreover, excreted FCM represents a cumulative corticosterone secretion over a number of hours, providing a more integrated measure of recent corticosterone secretion (Touma and Palme 2005; Sheriff et al. 2011). However, it is necessary to provide a successful physiological validation before a method can be reliably applied (Goymann 2005; Touma and Palme 2005; Palme 2005, 2012). The time delay between increased plasma corticosterone levels and their reflection in FCM is species-dependent; thus, it should be established for each species separately (Palme 2012). Similarly, due to speciesspecific differences in the excreted corticosterone metabolites (Palme et al. 2005), an enzyme immunoassay (EIA) for their determination has to be validated for each species (Möstl et al. 2005; Touma and Palme 2005; Palme et al. 2013). The most widely used experiment to perform this validation is an adrenocorticotropic hormone (ACTH) challenge test (Touma and Palme 2005). As ACTH is a pituitary hormone that stimulates corticosterone release by the adrenal cortex, samples collected at regular intervals, after ACTH stimulation, allow to determine the time required to obtain an increase in FCM in droppings (Touma and Palme 2005; Palme 2012).

The Little Auk (Alle alle), an Arctic seabird, breeding in large colonies in the high Arctic, constitutes an interesting species to study the response of individuals to environmental challenges and different energetic demands of the life cycle. It is socially and genetically monogamous (Wojczulanis-Jakubas et al. 2009) with a very slight sexual dimorphism (Jakubas and Wojczulanis 2007). The costs of parental care are similar in both sexes (Stempniewicz and Jezierski 1987; Wojczulanis-Jakubas et al. 2012). A single semi-precocial chick is reared annually in a nest concealed under the surface in extensive boulder screes (Stempniewicz 2001). Energy demands of Little Auk chicks (Konarzewski et al. 1993) and adults (Gabrielsen et al. 1991) are very high in comparison with other seabirds. Also, their maximum growth rates (g/day; expressed as a percentage of adult mass) are more than twice those of other Alcidae (Gaston 1985). To cover their extremely high energetic demands, Little Auks focus on copepods associated with cold Arctic waters (Kwasniewski et al. 2010; Jakubas et al. 2011). During the first week of chick rearing, both parents brood and provision the chick (Stempniewicz and Jezierski 1987; Harding et al. 2004; WojczulanisJakubas and Jakubas 2012). In the second week of chick rearing, the adults gradually reduce brooding, but continue to feed at a similar frequency (Harding et al. 2004; Wojczulanis-Jakubas and Jakubas 2012). In the third week, chicks increase their wing exercising activities outside the nest chamber (Stempniewicz 1995), the feeding rate remains constant (Stempniewicz and Jezierski 1987; Harding et al. 2004; Wojczulanis-Jakubas and Jakubas 2012), but the growth rate of chicks is evidently slower (Stempniewicz 1980; Gaston 1985; Konarzewski and Taylor 1989). Most chicks leave the colony at age of 25-27 days, but chicks as young as 20 days old have been reported to be fledged (Stempniewicz 2001; Harding et al. 2004). During the fourth and last week of chick rearing, some females may disappear from the colony (1-3 days before their chicks fledge), whereas males continue feeding and escort the fledgling during its colony departure (Stempniewicz 1980; Taylor 1994; Harding et al. 2004; Wojczulanis-Jakubas and Jakubas 2012). It is possible that brood desertion by one parent may trigger the offspring to fledge (Wojczulanis-Jakubas and Jakubas 2012).

The first aim of the study was to validate an appropriate EIA to measure FCM levels and to establish the time delay between increased plasma corticosterone levels and their reflection in the excreted FCM in Little Auks using the ACTH challenge test. The second aim was to examine the corticosterone response of Little Auks (observed in FCM levels) to the environmental challenges and different energetic demands. The FCM levels have been investigated in relation to weather conditions, week of chick rearing in adults, and age in chicks. As severe weather conditions may constitute a challenging factor for birds (Konarzewski and Taylor 1989; Romero et al. 2000; Wilson et al. 2004; Landys et al. 2006), it was hypothesised that the increased levels of FCM might occur in birds experiencing bad weather conditions. Plumage wetting due to rain coupled with cold temperature significantly affects the energetics and thermoregulation of birds (Wilson et al. 2004). Chicks are more vulnerable to the harsh, wet weather conditions than adults, as their body is not entirely covered with feathers until 21-23rd day of life (Stempniewicz 1980) and they have a higher surface to volume ratio that creates a higher loss of heat than seen in larger adults (Bicudo et al. 2010). The consecutive weeks of the chick-rearing period may differ in the energetic demands of chicks, and consequently alter corticosterone secretion in adults. The substantial increase in corticosterone secretion might be also expected in chicks, which are preparing for the first flight. 


\section{Methods}

\section{Study area}

The study was carried out in two Little Auk colonies: at Ariekammen slopes in Hornsund (SW Spitsbergen; $77^{\circ} 00^{\prime} \mathrm{N}, 15^{\circ} 33^{\prime} \mathrm{E}$ ) and at Alkekongen slopes in Magdalenefjorden (NW Spitsbergen; $79^{\circ} 35^{\prime} \mathrm{N}, 1^{\circ} 05^{\prime} \mathrm{E}$ ). Those colonies are the main breeding areas of Little Auks on Svalbard (Isaksen 1995). Birds from both colonies are characterised by similar body size parameters (Wojczulanis-Jakubas et al. 2011). However, it has been shown that birds from Magdalenefjorden colony perform foraging flights to more distant foraging areas compared with Hornsund (Jakubas et al. 2013). Nonetheless, no differences have been revealed between those two colonies in body condition and stress level (determined by sizeadjusted body mass and leucocytes proportion) of adults and chicks (Jakubas et al. 2011).

The mean daily temperatures and precipitation for the studied period, i.e. 8 July-12 August 2010, were taken from the Norwegian Meteorological Institute and Norwegian Broadcasting Corporation for both studied colonies (Fig. 1). In Hornsund, the meteorological station is located ca. $1 \mathrm{~km}$ from the studied colony. In Magdalenefjorden, the nearest meteorological station in Ny-Alesund $\left(78^{\circ} 55^{\prime} \mathrm{N}\right.$, $11^{\circ} 56^{\prime} \mathrm{E}$ ) is located ca. $75 \mathrm{~km}$ south of the colony; however, the weather data for Magdalenefjorden site are based on the modelling results (HIRLAM model) of the Norwegian Meteorological Institute and Norwegian Broadcasting Corporation. The data obtained for both colonies corresponded well with the direct observations of weather conditions, which were noted in the field.

\section{Fieldwork}

The validation of the adrenocorticotropic response (the ACTH challenge test) in Little Auks was conducted in the Magdalenefjorden colony in August 2011. Adults (sex determined molecularly afterwards: 4 males and 2 females) were captured with noose-carpets placed on the stones in the colony. Birds were injected subcutaneously (within 30 min after capturing) with an ACTH analogue (50 IU/kg body mass; Mark Chemicals, Darmstadt, Germany) and transferred to outdoor cages (dark wooden boxes, $30 \times 40 \mathrm{~cm}$, with plastic removable bottoms for collection of faecal samples). The detection of short peaks of metabolites requires a frequent sample collection (Möstl and Palme 2002); therefore, the faecal samples were collected every $15 \mathrm{~min}$ for 3-6 h (Palme 2012). After that time, birds were released unharmed. To test whether FCM excretion differed between adults and chicks, chicks of

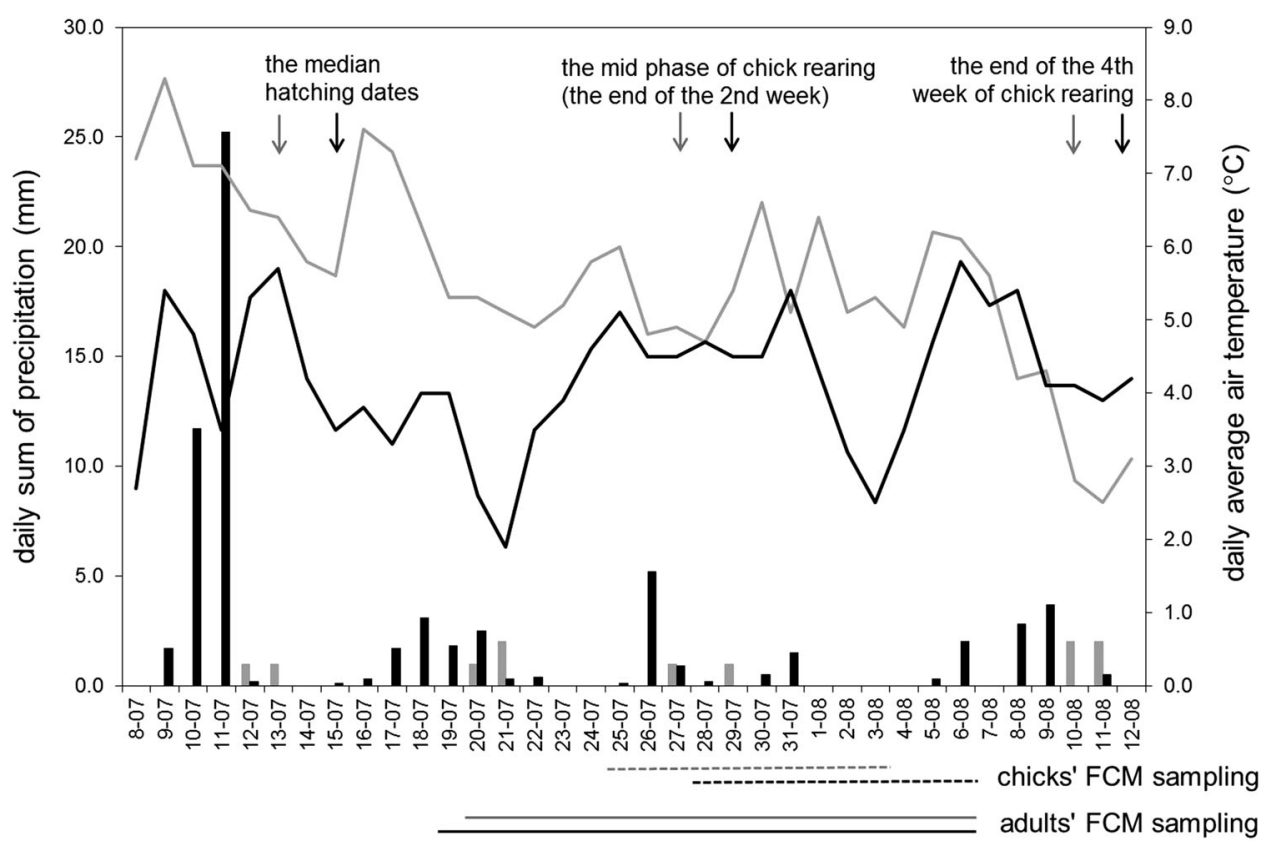

Fi. 1 The weather conditions (lines - temperature, bars-precipitation) in Hornsund (black) and Magdalenefjorden (grey) areas during the chick-rearing period of Little Auks (July-August 2010). Arrows indicate the median hatching dates, the mid-phase of chick rearing (the end of the 2 nd week) and the end of the 4 th week of chick rearing for two colonies (colonies differentiated by colours, as described above). Chick-rearing phases were calculated based on the median hatching dates. The time ranges of FCM sampling of adults (solid lines) and chicks (broken lines) in both colonies are indicated below. Meteorological data were obtained from the archive of Norwegian Meteorological Institute and Norwegian Broadcasting Corporation 
both sexes (sex determined molecularly afterwards: 3 males and 3 females) and of similar age (21-26 days; age determined by hatching date of each chick) were injected subcutaneously with the ACTH analogue (the same dosage and type as above) and released into the nests. The nests of studied focal chicks were first cleaned of old faeces, and a thin plastic sheet was placed at the bottom of the nest chamber. Faecal samples were collected every $30 \mathrm{~min}$ for 8-11 h. Each collected sample was frozen immediately at $-20{ }^{\circ} \mathrm{C}$ in a plastic tube. Afterwards, small blood sample $(20 \mu \mathrm{l})$ was collected from the brachial vein according to the standard procedure (Owen 2011) from both adults and chicks for molecular sexing.

Data for studying factors affecting FCM levels were collected in July-August 2010, simultaneously in the two colonies. The nests were monitored every 2 days before hatching, in order to estimate the chick hatching dates. Chicks were weighed with an electronic balance (OHAUS, accurate to $0.1 \mathrm{~g}$ ) beginning from the second week (i.e. chicks aged 11-14 days) and continued until the fourth week of chick rearing. The fledging age was not recorded for all studied chicks, due to the logistic constraints (the fieldwork terminated earlier than some of the later-hatched chicks fledged or the access to several chicks was limited when they moved deeper in the nest chambers). Droppings were collected from chicks taken from the nests. The collected faecal samples (one sample from each chick) were from chicks aged 11-23 days. Droppings from adults were collected during the 4 weeks of chick rearing, from individuals randomly captured in the colony with noose-carpets. Birds defecated immediately after capture (up to $1 \mathrm{~min}$ ). Each adult was sampled for faeces only once. All faecal samples were collected immediately in plastic tubes, labelled and maintained in a field cooler box with frozen gel packs for up to $2 \mathrm{~h}$ and then stored in a freezer at $-20{ }^{\circ} \mathrm{C}$ until analysis. As the corticosterone concentrations have been shown to fluctuate over a daily activity cycle in avian species (Breuner et al. 1999; Rich and Romero 2001; Quillfeldt et al. 2007), all samples were collected within the same and relatively short time window (9:00-14:00). In Hornsund, 36 samples were collected from adults and 48 from chicks, and in Magdalenefjorden 20 and 47 samples, respectively.

\section{Laboratory work}

All collected faecal samples were defrosted, mixed with $60 \%$ methanol (proportion: 1:20) and vortexed for $30 \mathrm{~min}$. Extracting faeces with a lower percentage of alcohol (e.g. $60 \%$ and not $80 \%$ methanol) is recommended for birds, from which faeces and urine are excreted together (Palme 2005; Palme et al. 2013). After centrifugation, the supernatant was transferred to a new tube and used for the analyses with various EIAs (Touma and Palme 2005).

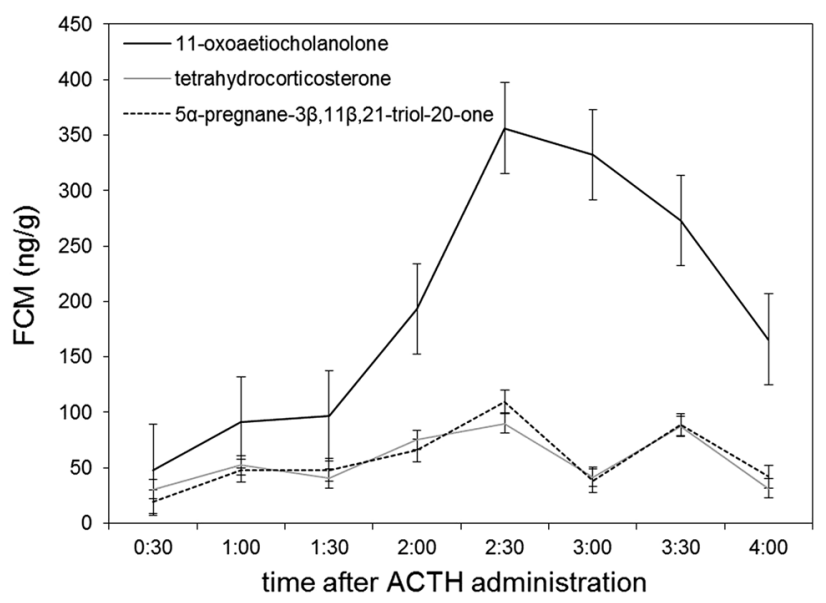

Fig. 2 The increase in FCM in the Little Auk's droppings observed during the ACTH challenge test. FCM levels were measured using three EIAs: 11-oxoaetiocholanolone, tetrahydrocorticosterone and $5 \alpha$ pregnane-3 $\beta, 11 \beta, 21$-triol-20-one. Samples from adult males and females combined $(N=6)$; values indicate mean $\pm \mathrm{SE}$

Samples obtained from the ACTH validation study were analysed first. Aliquots were measured using three EIAs: an 11-oxoaetiocholanolone (Möstl et al. 2002), a tetrahydrocorticosterone (Quillfeldt and Möstl 2003) and a 5 $\alpha$ pregnane-3 $\beta, 11 \beta, 21$-triol-20-one (Touma et al. 2003). Following ACTH administration, all assays showed an increase in immunoreactive substances measured in the droppings of Little Auks. The baseline-to-peak ratio was the highest using the 11-oxoaetiocholanolone-EIA (Fig. 2); thus, it was chosen for analysing the rest of the samples.

DNA for sexing was extracted from coagulated blood (after ethanol evaporation) using a Blood Mini Kit (A\&A Biotechnology, Gdynia, Poland). CHD gene-based analyses were performed with the primer pair F2550 and R2718, according to Griffiths et al. (1998) using a $50{ }^{\circ} \mathrm{C}$ annealing temperature for the PCR. The sex differences in the PCR products were clearly visible in UV light when the fragments were separated on a $2 \%$ agarose gel and stained with ethidium bromide.

\section{Data analysis}

Initial, maximum and time until the maximum concentration of FCM was reached during the ACTH challenge test were compared between Little Auk adults and chicks by ANOVA. The data met the assumptions of normality (Shapiro-Wilk tests, $P>0.05$ ) and homogeneity of variances (Levene's tests, $P>0.05$ ). Multiple regression models were used to investigate changes in FCM levels in relation to precipitation (daily sum), air temperature (daily average), week of chick rearing in adults, age in chicks, and colony. The assumptions of the regression models were met after log-transformation of variables (FCM levels of adults and chicks, precipitation, air temperature and age of chicks) using the natural 
logarithm (Zar 1999; Quinn and Keough 2002). The residuals in both regression models, performed for adults and for chicks, were normally distributed (Shapiro-Wilk tests, $P=0.76$ and $P=0.30$, respectively) and were not autocorrelated (Durbin-Watson tests, $d=2.0$ and $d=2.2$, respectively). The linearity of variables and homoscedasticity of residuals were confirmed by examining the bivariate scatterplots (Zar 1999; Quinn and Keough 2002). The precipitation and air temperature data included in the analysis were obtained from the same day, in which a faecal sample was taken from an adult/chick. In the regression model performed for adults, the cut-off points of the consecutive weeks of the chick-rearing period were distinguished according to the respective median date of hatching calculated for all nests in each colony, since adults were randomly caught at the colony surface (Fig. 1). In the regression model performed for chicks, the age was determined based on the hatching date of a given chick. As the data were obtained from two different Little Auks colonies, the colony was included as a predictor.

The relationships between FCM level and body mass or fledging age of chicks were tested using Pearson correlation coefficients. Data of FCM levels and body mass of chicks were normally distributed after log-transformation using the natural logarithm (Shapiro-Wilk tests, $P>0.1$ ). Since the growth curve measure in Little Auks is not influenced by the particular asymptote that individual chicks attain (Gaston 1985), it is better to compare the body mass at the particular phase of chick development (e.g. Jakubas et al. 2011). The correlation between FCM level and body mass was performed for chicks, for which both variables were obtained at the same age (14-15th day of life-the mid-phase of chick development). This phase was chosen, due to the largest amount of faecal samples collected from chicks of that age $(N=31)$. The correlation between FCM level and fledging age was performed for a group of chicks $(N=17)$, for which the fledging age was known and the faecal samples were collected at the same age (14-15th day of life). All statistical analyses were performed using STATISTICA 10.0 (StatSoft, Inc.). The critical alpha level was 0.05.

\section{Results}

\section{ACTH challenge test}

The initial concentrations of FCM were significantly lower in adults than in chicks (ANOVA, $F_{3,12}=11.4, P=0.007$; Table 1), whereas the maximum values of FCM concentrations after the ACTH stimulation were not significantly different in both age classes (ANOVA, $F_{3,12}=0.04$, $P=0.84$; Table 1). Consequently, in adults the peak values constituted up to tenfold higher concentrations compared
Table 1 Initial, maximum and time to maximum level of FCM in the Little Auk adults and chicks of both sexes during the ACTH challenge test

\begin{tabular}{lllll}
\hline & $\begin{array}{l}\text { Initial level } \\
(\mathrm{ng} / \mathrm{g})\end{array}$ & $\begin{array}{l}\text { Maximum level } \\
(\mathrm{ng} / \mathrm{g})\end{array}$ & $\begin{array}{l}\text { Time to } \\
\text { maximum } \\
\text { level (h) }\end{array}$ & $N$ \\
\hline Adults & & & & \\
Males & $27.9-66.2$ & $101.9-816.2$ & $2: 20-3: 00$ & 4 \\
Females & $41.3-91.2$ & $330.9-690.8$ & $2: 10-3: 00$ & 2 \\
Mean \pm SD & $52.4 \pm 23.4$ & $395.0 \pm 294.9$ & $2: 28 \pm 0: 40$ & 6 \\
Chicks & & & & \\
Males & $118.8-158.4$ & $146.3-392.7$ & $2: 10-4: 30$ & 3 \\
Females & $118.8-255.2$ & $198.1-966.9$ & $3: 15-4: 00$ & 3 \\
Mean \pm SD & $160.6 \pm 56.0$ & $394.9 \pm 306.6$ & $3: 29 \pm 1: 00$ & 6 \\
\hline
\end{tabular}

The ranges (min-max) are presented for adults and chicks of both sexes separately. The mean \pm SD values are presented for adults and chicks of both sexes combined

Table 2 Effects of precipitation, air temperature, week of chick rearing in adults, age in chicks, and colony on FCM levels of the Little Auk adults $(N=55)$ and chicks $(N=84)$ during the nesting period in two breeding colonies in Spitsbergen

\begin{tabular}{lll}
\hline Predictor & Adults & Chicks \\
\hline Precipitation $(\mathrm{mm})$ & $\beta=0.09$, & $\boldsymbol{\beta}=\mathbf{0 . 6 0}$, \\
& $t=0.33$, & $\boldsymbol{t}=\mathbf{2 . 9 8 ,}$ \\
& $P=0.75$ & $\boldsymbol{P}=\mathbf{0 . 0 0 4}$ \\
Air temperature $\left({ }^{\circ} \mathrm{C}\right)$ & $\beta=-0.37$, & $\beta=-0.75$, \\
& $t=-0.91$, & $t=-0.87$, \\
& $P=0.37$ & $P=0.39$ \\
Week of chick rearing & $\beta=-0.12$, & $\boldsymbol{\beta}=\mathbf{1 . 6 9}$, \\
$($ week)*/chick age $($ day) $* *$ & $t=-1.02$, & $\boldsymbol{t}=\mathbf{2 . 9 3 ,}$ \\
& $P=0.31$ & $\boldsymbol{P}=\mathbf{0 . 0 0 4}$ \\
Colony & $\boldsymbol{\beta}=\mathbf{0 . 7 2 ,}$ & $\beta=-0.17$, \\
& $\boldsymbol{t}=\mathbf{2 . 2 4 ,}$ & $t=-1.08$, \\
& $\boldsymbol{P}=\mathbf{0 . 0 3}$ & $P=0.28$ \\
\hline
\end{tabular}

Significant regression coefficients $(P<0.05)$ are shown in bold. Multiple regression analyses were calculated for adults and chicks separately

* Predictor for adults

** Predictor for chicks

with the initial levels, while in chicks the peak values were on average threefold higher compared with the initial concentrations. The time until the maximum concentration of FCM was reached was shorter in adults than in chicks (ANOVA, $F_{3,12}=7.72, P=0.02$; Table 1$)$.

FCM levels in the Little Auk adults and chicks

Multiple regression revealed that precipitation, air temperature and week of chick rearing did not affect the adults' FCM levels. Only the effect of the colony was significant 


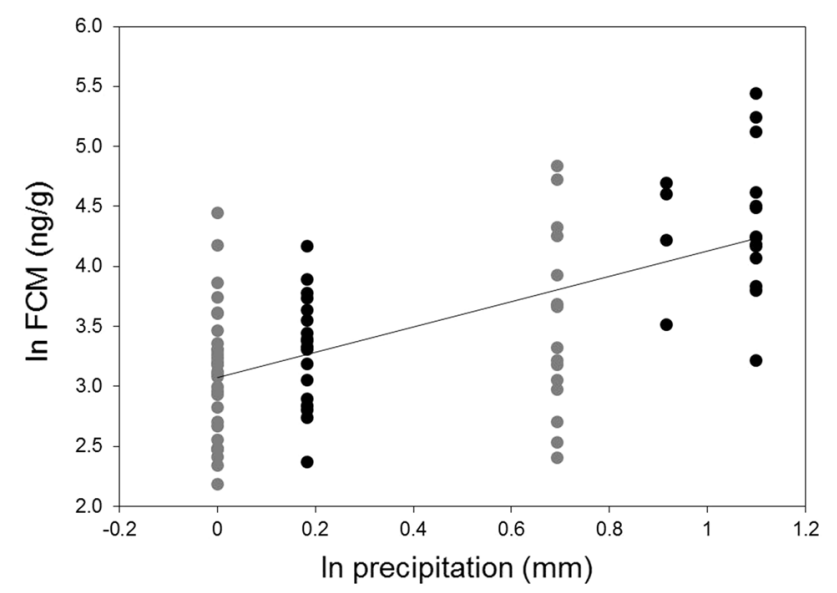

Fig. 3 The relationship between FCM levels in the Little Auk chicks and precipitation (daily sum). FCM levels significantly increased with precipitation (see Table 2 for detailed statistics). Data are presented for two colonies: Hornsund (black dots) and Magdalenefjorden (grey dots $)$ combined $(N=84)$

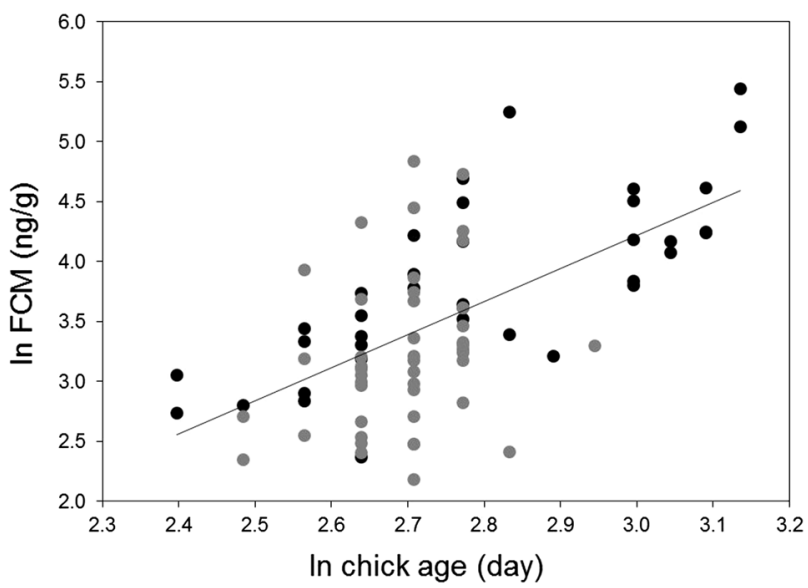

Fig. 4 The relationship between FCM levels and age in the Little Auk chicks. FCM levels significantly increased with advancement of chick age (see Table 2 for detailed statistics). Data are presented for two colonies: Hornsund (black dots) and Magdalenefjorden (grey dots $)$ combined $(N=84)$

(Table 2). In chicks, FCM levels increased with precipitation (Fig. 3) and with age (Fig. 4), but were unaffected by air temperature and colony (Table 2). Additionally, FCM levels negatively correlated with chicks' body mass (both parameters measured in chicks aged 14-15 days; $r_{p}=-0.38$, $t=-2.22, P=0.03, N=31$; Fig. 5). A positive relationship was revealed between FCM levels and fledging age of chicks $\left(r_{p}=0.51, t=2.31, P=0.04, N=17\right.$; Fig. 6$)$.

\section{Discussion}

The present study proposes a non-invasive method to evaluate adrenocortical activity in Little Auks by

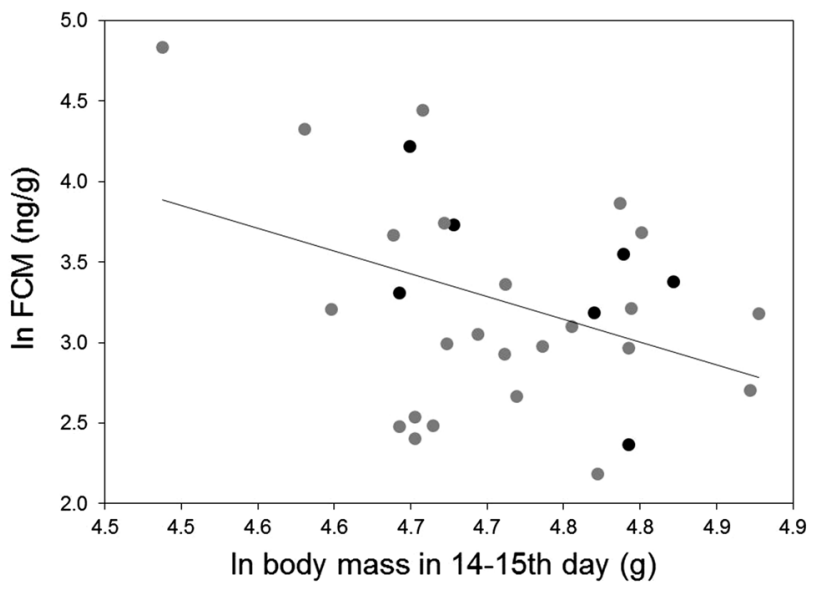

Fig. 5 The relationship between FCM levels and body mass in the mid-aged Little Auk chicks (14-15 days). The significant negative correlation was revealed (see text for detailed statistics). Data are presented for two colonies: Hornsund (black dots) and Magdalenefjorden (grey dots) combined $(N=31)$

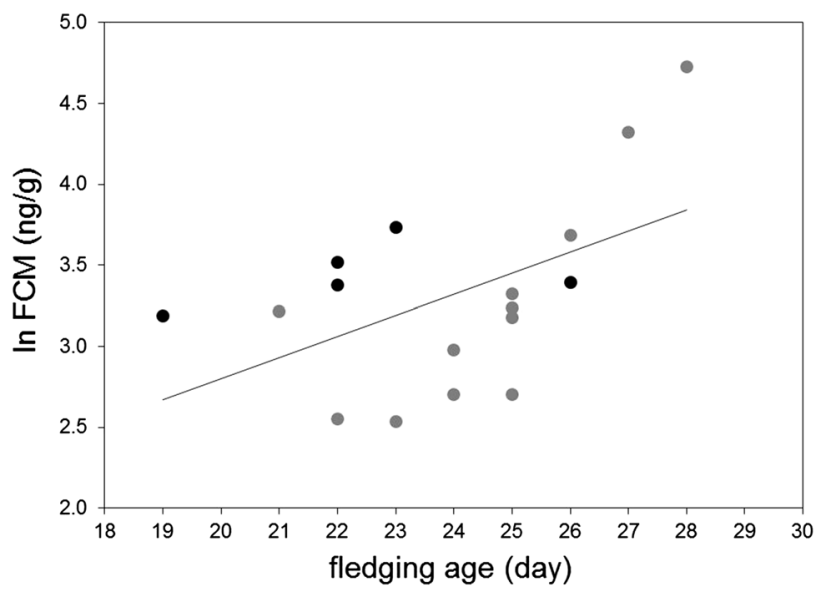

Fig. 6 The relationship between FCM levels measured in the midaged chicks (14-15 days) and their fledging age. The significant positive correlation was revealed (see text for detailed statistics). Data are presented for two colonies: Hornsund (black dots) and Magdalenefjorden (grey dots) combined $(N=17)$

measuring FCM levels. The 11-oxoaetiocholanolone-EIA for the FCM analysis was successfully validated for birds of both sexes and age groups. The peak increase in FCM levels, which occurred after 2-3 $\mathrm{h}$ in adults and after $2-4.5 \mathrm{~h}$ in chicks (Table 1), reflects the time between the peripheral corticosterone increase and faecal excretion (Palme et al. 2005; Palme 2012).

No effect of precipitation and air temperature on FCM level in adults was observed. However, periods of poor weather conditions (such as heavy fog or rain) may trigger a low colony attendance of birds (Stempniewicz 1986; Isaksen 1995), probably due the growing danger from the 
Glaucous Gulls (Larus hyperboreus) hunting in the colony area (Stempniewicz 1986, 1995). Even so, poor weather conditions, which occurred during the studied period, did not appear to be physiologically challenging for adults. Also, during the consecutive weeks of the chick-rearing period, the physiological state of birds seemed to be unchanged. Nonetheless, it is possible that the lack of changes in FCM levels during the 4 weeks of chick-rearing period were attributed to the relatively low sample size, since the stress-related heterophil to lymphocyte ratio in adults increased after hatching and then decreased in the last week of chick rearing (Wojczulanis-Jakubas et al. 2012). The only observed differences in adults' FCM levels occurred between the colonies. Those differences may reflect earlier documented differences in the foraging strategy of birds (different distances from colony to foraging ground for the two colonies), resulting from different characteristics of the foraging grounds in the proximity of the two colonies (Kwasniewski et al. 2010; Jakubas et al. 2011, 2013). In Hornsund colony (where FCM levels of adults were lower), the majority of birds' foraging locations were within $26-50 \mathrm{~km}$ from the colony, while foraging locations of Little Auks from Magdalenefjorden (where FCM levels of adults were higher) were $126-150 \mathrm{~km}$ from the colony (Jakubas et al. 2013). Similarly, in Thick-billed Murres (Uria lomvia) nesting at three colonies located at different distances from the productive continental shelf-break, birds performing further foraging flights had higher levels of corticosterone compared with murres nesting closer to the foraging location (Harding et al. 2013).

In contrast to adults, the FCM concentration in chicks was significantly affected by precipitation. This result is concordant with the previous findings denoting the negative influence of weather variables (especially precipitation and wind speed) on the growth rate and fat deposits of the Little Auk chicks (Konarzewski and Taylor 1989; Taylor and Konarzewski 1989). The Little Auk chicks are not well protected in their nests against prolonged or heavy rainfalls; thus, water gathering at the bottom of the nest chamber may lead to excessive heat loss (Konarzewski and Taylor 1989). Moreover, a rapid growth of contour feathers impairs the insulation, and the thermoregulation costs seem to be high for developing chicks. Nonetheless, the range of air temperatures observed during the study period did not appear to be challenging for chicks.

The increase in corticosterone levels with advancement of chick age was observed in the Little Auk chicks. Such pattern of changes has also been documented in several bird species (Heath 1997; Belthoff and Dufty 1998; Wada et al. 2007; Quillfeldt et al. 2010). This increase probably results from the activation of the adrenocortical response during nestling development, e.g. in White-crowned Sparrow chicks (Zonotrichia leucophrys), a robust increase in corticosterone occurred in the late nestling stage (Wada et al. 2007). The corticosterone may be involved in the physiological and behavioural adjustments, necessary for successful fledging and post-fledging survival. During the period preceding fledging, Little Auk chicks start to exercise their wings outside the nest chamber (Stempniewicz 1980, 1995); the observed increase in motoric activity might be supported by the increase in corticosterone level. At this time, chicks are more vulnerable to the Glaucous Gull predation (Stempniewicz 1995; Wojczulanis et al. 2005), which could additionally increase the FCM levels. The rise in corticosterone level might also be explained by the energetic and nutritional deprivation in chicks approaching fledging (Sprague and Breuner 2010; Quillfeldt et al. 2010). The energetic value of food load delivered to chicks appeared to be lower in the fourth week of chick rearing comparing to the earlier weeks (Jakubas et al. 2007). However, this pattern seems to be season dependent. Moreover, glucocorticoids might promote the availability of lipid energy from adipose tissue stores (Dallman et al. 1993). Thus, increased corticosterone levels observed around fledging may support lipid mobilisation required to fuel first flight and to help the fledgling to survive until it encounters its first prey (Quillfeldt et al. 2007). The other possible factors that may influence FCM levels are changes in gut flora and the corticosterone binding globulin, which may occur in developing chicks and affect the excreted metabolites levels (Stöwe et al. 2013).

The increased FCM levels corresponded to a lower body mass in the mid-aged chicks (14-15 days) and were associated with later fledging age. Similar relationship has been noted between chicks' body mass and plasma corticosterone levels (Harding et al. 2009). This suggests that the corticosterone level may be a good predictor of the chicks' body condition. Fledging in birds is an important life history transition, and the timing may be influenced by an individual's morphological and physiological state. In Thin-billed Prion (Pachyptila belcheri), chicks with higher corticosterone concentrations fledged later in seasons evidencing worse foraging conditions (Quillfeldt et al. 2010). Similarly, in the Little Auk, later fledging chicks with higher corticosterone concentrations may be the ones that had to extend their growth in the nest, until they reach a fledging threshold (i.e. a proper level of wing development and wing loading; Stempniewicz 1982).

In conclusion, the present study showed that measuring FCM in droppings can be used as a reliable method for investigating the corticosterone secretion in the Little Auk. Furthermore, the study revealed that Little Auk chicks show increased corticosterone levels during unfavourable weather conditions, whereas different FCM levels in adults probably reflect different foraging efforts. The increase in 
chicks' FCM concentrations with their age, as well as the correlation of FCM levels with body mass and fledging age, may suggest that corticosterone is a good indicator of chicks' body condition and plays an important role in the transition from a sedentary lifestyle to flying and foraging independently.

Acknowledgments All fieldwork was done with the permission of the Norwegian Animal Research Authority and the Governor of Svalbard. Thanks go to Dr. Lech Iliszko, Dr. Katarzyna Pińska, Dr. Adam Nawrot and Magda Hadwiczak for their assistance in the field and to Monika Höring for FCM analysis. We appreciate the improvements in English usage made by Phil Whitford through the Association of Field Ornithologists' program of editorial assistance. The project was supported financially by the resources from National Science Centre in Poland based on the decision (DEC-2011/01/N/ NZ8/04569), University of Gdańsk Grant (538-L120-0794-12) and from Norway through the Norwegian Financial Mechanism (ALKEKONGE, PNRF-234-AI-1/07).

Open Access This article is distributed under the terms of the Creative Commons Attribution License which permits any use, distribution, and reproduction in any medium, provided the original author(s) and the source are credited.

\section{References}

Angelier F, Wingfield JC, Weimerskirch H, Chastel O (2010) Hormonal correlates of individual quality in a long-lived bird: a test of the 'corticosterone-fitness hypothesis'. Biol Lett 6:846-849. doi:10.1098/rsbl 2010.0376

Axelrod J, Reisine TD (1984) Stress hormones: their interaction and regulation. Science 224:452-459. doi:10.1126/science.6143403

Belthoff JR, Dufty AM Jr (1998) Corticosterone, body condition and locomotor activity: a model for dispersal in screech-owls. Anim Behav 55:405-415. doi:10.1006/anbe 1997.0625

Bicudo JEPW, Buttemer WA, Chappell MA, Pearson JT, Bech C (2010) Ecological and environmental physiology of birds. Oxford University Press, New York. doi:10.1093/acprof:oso/ 9780199228447.001.0001

Bonier F, Martin PR, Moore IT, Wingfield JC (2009) Do baseline glucocorticoids predict fitness? Trends Ecol Evol 24:634-642. doi:10.1016/j.tree.2009.04.013

Breuner CW, Wingfield JC, Romero LM (1999) Diel rhythms of basal and stress-induced corticosterone in a wild, seasonal vertebrate, Gambel's white-crowned sparrow. J Exp Zool 284:334-342. doi:10.1002/(SICI)1097-010X(19990801)284:3<334::AID-JEZ11> 3.0.CO;2-\#

Cherel Y, Robin J-P, Heitz A, Calagary C, Le Maho Y (1992) Relationships between lipid availability and protein utilization during prolonged fasting. J Comp Physiol B 162:305-313. doi:10.1007/BF00260757

Dallman MF, Strack AM, Akana SF, Bradbury MJ, Hanson ES, Scribner KA, Smith M (1993) Feast and famine: critical role of glucocorticoids with insulin in daily energy flow. Front Neuroendocrinol 14:303-347. doi:10.1006/frne 1993.1010

Frigerio D, Dittami J, Möstl E, Kotrschal K (2004) Excreted corticosterone metabolites co-vary with air temperature and air pressure in male Graylag geese (Anser anser). Gen Comp Endocrinol 137:29-36. doi:10.1016/j.ygcen.2004.02.013

Gabrielsen GW, Taylor JRE, Konarzewski M, Mehlum F (1991) Field and laboratory metabolism and thermoregulation in dovekies (Alle alle). Auk 108:71-78
Gaston AJ (1985) Development of the young in the Atlantic Alcidae. In: Nettleship DN, Birkhead TR (eds) The Atlantic Alcidae: the evolution, distribution and biology of the auks inhabiting the Atlantic Ocean and adjacent water areas. Academic Press, London, pp 319-354

Goymann W (2005) Noninvasive monitoring of hormones in bird droppings. physiological validation, sampling, extraction, sex differences, and the influence of diet on hormone metabolite levels. Ann NY Acad Sci 1046:35-53. doi:10.1196/annals.1343. 005

Griffiths R, Double MC, Orr K, Dawson RJG (1998) A DNA test to sex most birds. Mol Ecol 7:1071-1075

Harding AMA, Van Pelt TI, Lifjeld JT, Mehlum F (2004) Sex differences in Little Auk Alle alle parental care: transition from biparental to paternal-only care. Ibis 146:642-651. doi:10.1111/ j.1474-919X.2004.00297.x

Harding AMA, Kitaysky AS, Hall ME, Welcker J, Karnovsky NJ, Talbot SL, Hamer KC, Gremillet D (2009) Flexibility in the parental effort of an Arctic-breeding Seabird. Funct Ecol 23:348-358. doi:10.1111/j.1365-2435.2008.01488.x

Harding A, Paredes R, Suryan R, Roby D, Irons D, Orben R, Renner H, Young R, Barger C, Dorresteijn I, Kitaysky A (2013) Does location really matter? An inter colony comparison of seabirds breeding at varying distances from productive oceanographic features in the Bering Sea. Deep-Sea Res II. doi:10.1016/j.dsr2. 2013.03.013

Heath J (1997) Corticosterone levels during nest departure of juvenile American kestrels. Condor 99:806-811

Isaksen K (1995) The breeding population of Little Auk (Alle alle) in colonies in Hornsund and northwestern Spitsbergen. In: Isaksen K, Bakken V (eds) Seabird population in the northern Barents Sea. Meddelelser nr 135. Norsk Polar Institutt, Oslo, pp 49-57

Jakubas D, Wojczulanis K (2007) Predicting the sex of Dovekies by discriminant analysis. Waterbirds 30:92-96. doi:10.1675/15244695(2007)030[0421:RODTCI]2.0.CO;2

Jakubas D, Wojczulanis-Jakubas K, Walkusz W (2007) Response of dovekie to changes in food availability. Waterbirds 30:421-428

Jakubas D, Głuchowska M, Wojczulanis-Jakubas K, Karnovsky NJ, Keslinka L, Kidawa D, Walkusz W, Boehnke R, Cisek M, Kwasniewski S, Stempniewicz L (2011) Foraging effort does not influence body condition and stress level in Little Auks. Mar Ecol Prog Ser 432:277-290. doi:10.3354/meps09082

Jakubas D, Trudnowska E, Wojczulanis-Jakubas K, Iliszko L, Kidawa D, Darecki M, Błachowiak-Samołyk K, Stempniewicz L (2013) Foraging closer to the colony leads to faster growth in Little Auks. Mar Ecol Prog Ser 489:263-278. doi:10.3354/meps10414

Konarzewski M, Taylor JRE (1989) The influence of weather conditions on growth of Little Auk Alle alle chicks. Ornis Scand 20:112-116

Konarzewski M, Taylor JRE, Gabrielsen GW (1993) Chick energy requirements and adult energy expenditures of dovekies (Alle alle). Auk 110:343-353

Kwasniewski S, Gluchowska M, Jakubas D, Wojczulanis-Jakubas K, Walkusz W, Karnovsky N, Blachowiak-Samolyk K, Cisek M, Stempniewicz L (2010) The impact of different hydrographic conditions and zooplankton communities on provisioning Little Auks along the west coast of Spitsbergen. Prog Oceanogr 87:72-82. doi:10.1016/j.pocean.2010.06.004

Landys MM, Ramenofsky M, Wingfield JC (2006) Actions of glucocorticoids at a seasonal baseline as compared to stressrelated levels in the regulation of periodic life processes. Gen Comp Endocrinol 148:132-149. doi:10.1016/j.ygcen.2006.02. 013

Möstl E, Palme R (2002) Hormones as indicators of stress. Domest Anim Endocrinol 23:67-74. doi:10.1016/S0739-7240(02) 00146-7 
Möstl E, Maggs JL, Schrötter G, Besenfelder U, Palme R (2002) Measurement of cortisol metabolites in faeces of ruminants. Vet Res Commun 26:127-139. doi:10.1023/A:1014095618125

Möstl E, Rettenbacher S, Palme R (2005) Measurement of corticosterone metabolites in birds' droppings: an analytical approach. Ann N Y Acad Sci 1046:17-34. doi:10.1196/annals.1343.004

Owen JC (2011) Collecting, processing, and storing avian blood: a review. J Field Ornithol 82:339-354

Palme R (2005) Measuring faecal steroids: guidelines for practical application. Ann NY Acad Sci 1046:75-80. doi:10.1196/annals. 1343.007

Palme R (2012) Monitoring stress hormone metabolites as a useful, non-invasive tool for welfare assessment in farm animals. Anim Welf 21:331-337. doi:10.7120/09627286.21.3.331

Palme R, Rettenbacher S, Touma C, El-Bahr SM, Möstl E (2005) Stress hormones in mammals and birds. Comparative aspects regarding metabolism, excretion, and noninvasive measurement in fecal samples. Ann NY Acad Sci 1040:162-171. doi:10.1196/ annals.1327.021

Palme R, Touma C, Arias N, Dominchin MF, Lepschy M (2013) Steroid extraction: get the best out of faecal samples. Wien Tierarztl Monatsschr 100:238-246

Quillfeldt P, Möstl E (2003) Resource allocation in Wilson's stormpetrels (Oceanites oceanicus) determined by measurement of glucocorticoid excretion. Acta Ethol 5:115-122. doi:10.1007/ s10211-003-0074-9

Quillfeldt P, Poisbleau M, Chastel O, Masello JF (2007) Corticosterone in thin-billed prion Pachyptila belcheri chicks: diel rhythm, timing of fledging and nutritional stress. Naturwissenschaften 94:919-925. doi:10.1007/s00114-007-0275-6

Quillfeldt P, Poisbleau M, Schwabl I, Chastel O, Masello JF (2010) Corticosterone at fledging depends on nestling condition, not on parental desertion. Open Access Anim Physiol 2:61-68. doi:10. 2147/OAAP.S12819

Quinn GP, Keough MJ (2002) Experimental design and data analysis for biologists. Cambridge University Press, Cambridge

Rich EL, Romero LM (2001) Daily and photoperiod variations of basal and stress-induced corticosterone concentrations in house sparrows (Passer domesticus). J Comp Physiol B 171:543-547. doi: $10.1007 / \mathrm{s} 003600100204$

Romero LM (2002) Seasonal changes in plasma glucocorticoid concentrations in free-living vertebrates. Gen Comp Endocrinol 128:1-24. doi:10.1016/S0016-6480(02)00064-3

Romero LM, Reed JM (2005) Collecting baseline corticosterone samples in the field: is under $3 \mathrm{~min}$ good enough? Comp Biochem Physiol A: Mol Integr Physiol 140:73-79. doi:10.1016/ j.cbpb.2004.11.004

Romero LM, Reed JM, Wingfield JC (2000) Effects of weather on corticosterone responses in wild free-living passerine birds. Gen Comp Endocrinol 118:113-122. doi:10.1006/gcen 1999.7446

Sapolsky RM, Romero LM, Munck AU (2000) How do glucocorticoids influence stress-responses? Integrating permissive, suppressive, stimulatory, and adaptive actions. Endocr Rev 21:55-89. doi:10.1210/er.21.1.55

Sheriff MJ, Dantzer B, Delehanty B, Palme R, Boonstra R (2011) Measuring stress in wildlife: techniques for quantifying glucocorticoids. Oecologia 166:869-887. doi:10.1007/s00442-0111943-y

Sprague RS, Breuner CW (2010) Timing of fledging is influences by glucocorticoid physiology in Laysan Albatross chicks. Horm Behav 58:297-305. doi:10.1016/j.yhbeh.2010.03.002

Stempniewicz L (1980) Factors influencing the growth of the Little Auk, Plautus alle (L.), nestlings on Spitsbergen. Ekol Pol 28:557-581
Stempniewicz L (1982) Body proportions in adults and fledglings of the Little Auk. Acta Zool Crac 26:149-158

Stempniewicz L (1986) Factors causing changes in the rhythm of attendance of the Little Auks, Plautus alle (L.), at a colony during the breeding season in Svalbard. Ekol Pol 34:247-263

Stempniewicz L (1995) Predator-prey interactions between glaucous gull Larus hyperboreus and Little Auk Alle alle in Spitsbergen. Acta Ornithol 29:155-170

Stempniewicz L (2001) Alle alle Little Auk. BWP update. J Birds West Palearct 3:175-201

Stempniewicz L, Jezierski J (1987) Incubation shifts and chick feeding rate in the Little Auk Alle alle in Svalbard. Ornis Scand 18:152-155

Stöwe M, Rettenbacher S, Busso JM, Grasse A, Mahr K, Vogl W, Winkler H, Möstl E (2013) Patterns of excreted glucocorticoid metabolites change during development-analytical and physiological implications. Wien Tierarztl Monat 100:271-282

Taylor JRE (1994) Changes in body mass and body reserves of breeding Little Auks (Alle alle L.). Pol Polar Res 123:149-168

Taylor JRE, Konarzewski M (1989) On the importance of fat reserves for the Little Auk (Alle alle) chicks. Oecologia 81:551-558. doi:10.1007/BF00378968

Touma C, Palme R (2005) Measuring fecal glucocorticoid metabolites in mammals and birds: the importance of validation. Ann NY Acad Sci 1046:54-74. doi:10.1196/annals.1343.006

Touma C, Sachser N, Möstl E, Palme R (2003) Effects of sex and time of day on metabolism and excretion of corticosterone in urine and feces of mice. Gen Comp Endocrinol 130:267-278. doi:10.1016/S0016-6480(02)00620-2

Wada H, Hahn TP, Breuner CW (2007) Development of stress reactivity in white-crowned sparrow nestlings: total corticosterone response increases with age, while free corticosterone response remains low. Gen Comp Endocrinol 150:405-413. doi:10.1016/j.ygcen.2006.10.002

Wilson GR, Cooper SJ, Gessaman JA (2004) The effects of temperature and artificial rain on the metabolism of American kestrels (Falco sparverius). Comp Biochem Physiol A 139:389-394. doi:10.1016/j.cbpb.2004.10.009

Wingfield JC (1994) Modulation of the adrenocortical response in birds. In: Davey KG, Peter RE, Tobe SS (eds) Perspectives in comparative endocrinology. National Research Council of Canada, Ottawa, pp 520-528

Wojczulanis K, Jakubas D, Stempniewicz L (2005) Changes in the glaucous gull predatory pressure on Little Auks in Southwest Spitsbergen. Waterbirds 28:430-435. doi:10.1675/15244695(2005)28[430:CITGGP]2.0.CO;2

Wojczulanis-Jakubas K, Jakubas D (2012) When and why does my mother leave me? The question of brood desertion in the Dovekie (Alle alle). Auk 129:632-637. doi:10.1525/auk.2012. 12095

Wojczulanis-Jakubas K, Jakubas D, Oigarden T, Lifjeld JT (2009) Extrapair copulations are frequent but unsuccessful in a highly colonial seabird, the Little Auk, Alle alle. Anim Behav 77:433-438. doi:10.1016/j.anbehav.2008.10.019

Wojczulanis-Jakubas K, Jakubas D, Welcker J, Harding AMA, Karnovsky NJ, Kidawa D, Steen H, Stempniewicz L, Camphuysen CJ (2011) Body size variation of a high-Arctic seabird: the dovekie (Alle alle). Polar Biol 34:847-854. doi:10.1007/s00300010-0941-6

Wojczulanis-Jakubas K, Jakubas D, Kidawa D, Kośmicka A (2012) Is the transition from biparental to male-only care in a monogamous seabird related to changes in body mass and stress level? J Ornithol 153:783-800. doi:10.1007/s10336-011-0796-9

Zar JH (1999) Biostatistical analysis. Prentice Hall, New Jersey 